\title{
Literature Review on Project and Organizational Factors for Project Performance
}

\author{
Ammar Ali ${ }^{1}$, K. Ramanathan ${ }^{2}$ \\ Post Graduate Center, Limkokwing University of Creative Technology, Malaysia ${ }^{1,2}$
}

\begin{abstract}
Critical Success Factor (CSF) is necessary in construction industry to achieve its goal. Construction industry in India has shown a significant development in recent years and its effect on environment has also increased. Building projects are becoming more difficult and complex nowadays. The project team is facing unprecedented changes. Building maintenance play an important role compared to other factors in building operation. Also, construction research and development process has various factors which affect its success. The earlier approach to success in the construction industry places great emphasis on the ability to plan and implement projects. In the past, companies completing projects in a timely manner within a stipulated budget and meeting optimum quality have been considered successful companies. Minimizing an importance on management practices and organizational stability, companies with successful project completion have been considered as top-performers. In contrast, other industries insist management practices at a corporate level as an essential element of success. However, the future environment of the construction company will be different due to technological and economic advancements. The critical success factors are considered to improve effectiveness and efficiency of the project. The aim of this study is to identify the critical success factor, analyse them and point out which critical factors are important in stages of construction. Some of the factors are identified as crucial to success of the project.
\end{abstract}

Keywords: Critical Success Factor (CSF), Client-related factors, Contractor-related factors, Consultant-related factors, Material-related factors, European Union (EU), Key Performance Indicators (KPIs)

\section{INTRODUCTION}

Construction industry has complexity in its nature because it contains a large number of parties such as clients, contractors, consultants, stakeholders, shareholders, regulators and others. Construction industry makes significant contributions to the socio-economic development process of a country. Its importance emanates largely from the direct and indirect impact it has on all economic activities. It contributes to the national output and stimulates the growth of other sectors through a complex system of linkages. It is noted that about one-tenth of the global economy is dedicated to constructing and operating homes and offices (UNEP, 1996). UNEP further observes that the industry consumes one-sixth to one half of the world's wood, minerals, water and energy. It contributes to employment and creates income for the population and has multiplier effects on the economy. The construction industry employs large unskilled labor. Throughout the developing world, the majority of employees in the industry are unskilled. Women are also found to be beneficiaries of the employment in the industry. However, the employment in the industry is mainly temporary in nature and once the job is over, the workers are obliged to find other jobs or return to their place of origin.

In construction projects, delays, cost overruns, stakeholder issues, conflicts, litigations, arbitrations, abandonment and other factors influences project performance. For more than 40 years, this has been the subject of interest of researchers in various parts of the world. Researchers have found differing results in their studies on the critical success factors (CSFs) and their cause-and-effect on project performance. In this chapter, the various perspectives of past research on factors impacting project performance with respect to project-related factors, such as client-related factors, contractorrelated factors, consultant-related factors, material-related factors, labor and equipment-related factors, contract management-related factors, externally-related factors and project management tools/ techniques-related factors, are reviewed critically. Additionally, organizational related factors, such as leadership, organizational culture, innovation and learning organization and their impact on project performance are analyzed critically. A total of 64 articles (31 articles on project-related factors and 33 articles on organizational-related factors) on project performance from reputed journals covering the period from 1985 to 2015 (30 years) were reviewed critically to summarize their findings and to identify the research gap/s. Detailed literature review matrix is shown in Appendix A.

\section{LITERATURE REVIEW}

Many researchers have studied the systems of control of the elements of the construction project, the [1], the importance and the significance of the administrative on the performance of the construction projects in terms of the 


\section{International Advanced Research Journal in Science, Engineering and Technology}

Vol. 6, Issue 5, May 2019

time completed by the poll of the group of project managers in both the consulting offices and contracting companies has concluded by the researcher that the leadership competence represented (leadership capabilities, selection of human elements, the skill of dealing with time) and administrative efficiency in its dimensions (team building, understanding of the internal environment of the contractor, human relations between management and staff) have an impact on the time set to accomplish construction projects.

While [2] that most of the factors affecting the delay in construction projects lie in the planning stage. Where the ten most important factors contributing to the delay of construction projects in Iraq, the most important of which is the poor planning of the project, timetable and the financial difficulties faced by the contractor. Bad estimates of costs, bad management and supervision, inefficient working methods and insufficient number of equipment, labor and construction materials.

While the study of [3] after the formation of task forces and leadership on the performance of construction companies for construction projects in Jordan, where the study was conducted in Jordan and applied a study on 115 government construction projects and aimed to explain the impact of environmental and regulatory factors on the performance of contractors construction projects has summarized the study to the presence Effect of statistical significance of these changes on the time and cost of the work to be done.

While the study showed [5] how to manage quality in construction projects in Syria this study concluded that the construction projects in Syria suffer from some imbalances and shortcomings the research presented some solutions and suggestions that could contribute to avoiding some quality management problems in this industry.

\section{a. Project performance}

Egwunatum [5], found in their studies, that the relationship between various independent variables and project success varies according to the project life cycle. [6], found in his research, that CSFs do not give real life knowledge of a project's success.

\section{- Time}

According to Demirkesen \& Ozorhon, [25], scope of work impacts project lead time considerably in all the projects. Hence, proper scope management is the key to achieve the project time schedules. [7] stated that though project success is dependent upon macro as well as micro-perspectives, timely completion of the project is the key for project success.

\section{Cost}

Olugbenga [26], found in their study, that cost overrun is an important factor for project failure in construction projects; losses and expenses claim during delay periods are significantly impacting project performance in Nigeria. Additionally, they found that contingency budgets estimated during the pre-contract stage are inadequate to cover the cost overruns and losses.

\section{- Quality}

Egwunatum [5], found in their studies that, quality deviations in construction projects in terms of repair and re-work lead to $12.4 \%$ hike in total project costs. [9] stated that quality is a critical factor for project success in construction projects. [10], found in their studies that, project manager's competence and top management support significantly contribute to the quality in construction projects.

\section{- Safety}

Abdullah A. Khawam, Nancy [11] critically analyzed the various concepts of project, project management, project performance, individual skills and competencies and the other social arrangements involved in a project. They questioned the iron triangle concepts of project management such as time, cost and quality. These concepts have been kept at status quo for the last few decades. They suggested that, studies are not available on other indicators of project performance, such as health \& safety and ethics and economy and these areas need to be explored further.

\section{Financial}

Moschouli et al., [12] suggested the need to have a proper management information system (MIS) to compliment project success. The same is endorsed by [13], that application of proper project management techniques will lead to project success. [14] argued that apart from time, cost and quality performance of the project, stakeholders and benefits to stakeholders should also be measured as part of the project's success. 


\section{International Advanced Research Journal in Science, Engineering and Technology}

Vol. 6, Issue 5, May 2019

III.

PROJECT-RELATED FACTORS

Alaloul et al., [15], found in his studies, that [16] CSFs, such as project management personnel, their technical tasks, monitoring and feedback, communication and troubleshooting, are some of the factors positively correlated for project success in manufacturing-related projects in Iraq. [17], found in their studies, that success judgment by various stakeholders during conceptualization, planning, implementation and closing phases of the project life is critical for the success of the projects in developing countries in not-for-profit international development projects.

Client-related factors: According to Alaloul et al., [15], clients should take an increased role in ensuring the success of their projects. He also stated that client's selection of the right project and dropping potentially unsuccessful projects are the keys to project success. [19] stated that though project success is dependent on perspectives, from a macro point of view, client satisfaction is the key factor, which determines project success.

Contractor-related factors: Olugbenga [20] stated that stakeholders, such as subcontractors and their interest in a project, is a key factor for project success along with other CSFs. [21], found in their studies, that problems with subcontractors and mistakes during the construction stage, are the most important causes for delays in construction projects in Iraq.

Consultant-related factors: Sami [22] found in their studies that, role of consultants in a project is important and their interest in a project will lead to less technical problems and will lead to project success. [18], found in their studies, that consultant-related factors are one of the four main causes for delays in construction projects in Iraq. [12] found that consultants are important for project success in not for-profit international projects in developing countries.

Material-related factors: Olugbenga [26], explained in his research that there exist different structures and supplier relationships between various countries, such as the USA, the European Union (EU) countries and Japan. These different supplier structures and relationships significantly lead to difference in project performance in these countries. [2] found that, supplier's performance in terms of supplying material on time with right quality is an important factor for the success of the projects.

\section{Contract Management-Related Factors}

According to Olugbenga [26], scope differs significantly in the industry even for comparable projects and impacts project performance. [21] stated that, established procedures for project scope changes and control of these scope changes are important for project success. He argued that scope changes in a project significantly impact project performance in terms of cost, time and other areas. [11] stated that contract management is one of the six key factors for achieving project success.

\section{Organizational-Related Factors}

Zidane [27], found in his studies, that traditionally, project management is deeply rooted to the hard paradigms, such as clients, consultants, suppliers, subcontractors, labor \& equipment, contract management, external factors and project management tools/techniques. However, in the recent past, the theoretical frameworks on soft paradigms, such as leadership, organizational culture, innovation, learning organization and communication and their impact on project management, have rapidly expanded. He also found that the influence of soft paradigms on project management is substantial and both hard and soft paradigms are dependent on each other to compliment project performance.

\section{Leadership-Related Factors}

Long et al., [3] argued that apart from many CSFs which influence project success or failure, a project manager's management and leadership skills are important for the project's success. [22] suggested that top management of project management companies must clearly specify project objectives as early as possible even before the project starts.

\section{Organizational Culture-Related Factors}

Rooij et al., [6] argued that project management team members' technical background is crucial for the success of projects. However, [8], found in their research, that a project management team is not fully responsible for the success or failure of their project. They further suggested that the project management team members' role should be appreciated.

\section{Innovation-Related Factors}

Dubois and Gadde [28], found in their studies, that the construction industry's pattern of connections, short-term productivity and fast decision-making hampers innovation. They also found that the construction industry players behave differently with one another and since projects are temporary in nature, not much attention is paid to innovation and thus, not promoted. Additionally, they stated that government regulations and industry standards hamper 


\section{International Advanced Research Journal in Science, Engineering and Technology}

Vol. 6, Issue 5, May 2019

innovation in the construction industry. [7], found in his research that, innovation as a concept and its impact on project success have not been studied in detail in the construction industry.

\section{Learning Organization-Related Factors}

Rooij et al., [6] stated that many of the continuous improvement programs in organizations fail and suggested three critical issues, i.e., well-grounded definition, clear operational guidelines and better tools for measurement for learning organizations to be successful.

\section{PROJECT SUCCESS AND PROJECT PERFORMANCE}

Kissi et al., [4], stated that the success of any project is related to two important features, which are service quality in construction delivered by contractors and the project owner's expectations. Managing the construction so that all the participants perceive equity of benefits can be crucial to project success. It is obtained that the complete lack of attention devoted to owner's satisfaction contributes to poor performance. Declining market shares, low efficiency and productivity, and the rapid construction cost escalation also lead to poor performance.

Sirisomboonsuk et al [14] remarked that the success of construction projects depends up on technology, process, people, procurement, legal issues, and knowledge management which must be considered equally.

Kissi et al., [4], defined project success as the completion of a project within acceptable time, cost and quality and achieving client's satisfaction. Project success can be achieved through the good performance of indicators of the project.

So, success refers to project success and performance refers to performance of indicators such as project managers. [12] stated that Project success has been widely discussed in the project management literature. The focus of most studies of project success is on dimensions of project success (how to measure it) and factors influencing project success. [19] studied that how the engineers evaluate project success and to what extent key project stakeholders' performance correlates with project success. It is obtained that project owners play the most important role in determining project success, and project management organizations' performance as the single point of project responsibility has significant correlations with project success criteria. $[1,2]$ stated that the allocation of risk among the contracting parties in a construction contract is an important decision leading to the project success.

\section{CONSTRUCTION PROJECTS AND PERFORMANCE}

Success of construction projects depends mainly on success of performance. Many previous researches had been studied performance of construction projects. [5] remarked that one of the principle reasons for the construction industry's poor performance has been attributed to the inappropriateness of the chosen procurement system. [16] remarked three important structures underlying the dynamic of a project performance which are: the work accomplishment structure, feedback effects on productivity and work quality and effects from upstream phases to downstream phases. [17] identified the main performance criteria of construction projects as financial stability, progress of work, standard of quality, health and safety, resources, relationship with clients, relationship with consultants, management capabilities, claim and contractual disputes, relationship with subcontractors, reputation and amount of subcontracting.

Demirkesen \& Ozorhon, [25], stated that construction time is increasingly important because it often serves as a crucial benchmarking for assessing the performance of a project and the efficiency of the project organization.

Egwunatum [5], identified project performance categories such as people, cost, time, quality, safety and health, environment, client satisfaction, and communication.

It is obtained by [15] that a control system is an important element to identify factors affecting construction project effort. For each of the project goals, one or more Project Performance Indicators (PPI) is needed. [15] obtained that human factors played an important role in determining the performance of a project. [23] remarked that both early contractor involvement (ECI) and early supplier involvement (ESI) would minimize constructability-related performance problems including costs associated with delays, claims, wastages and rework, etc. [15] obtained that the most important of practices relating to scope management are controlling the quality of the contract document, quality of response to perceived variations and extent of changes to the contract. It was recommended for foreign firms to adopt some of the project management practices highlighted to help them to achieve better project performance in China. 


\section{International Advanced Research Journal in Science, Engineering and Technology}

Vol. 6, Issue 5, May 2019

\section{DISCUSSION}

The construction industry can be considered as a powerful industry, however continually faces challenges. These challenges and numerous of the participants in this sort of extend make it troublesome to control costs, which leads to cost overruns. As a result, cost overruns are considered one of the foremost critical issues within the usage of construction projects [11], [26]. As [27] said, fetched overwhelms can cause a extend to fall flat. The taken a toll overwhelm is basically characterized as the contrast between the real last taken a toll of the development venture upon completion and the sum of the contract concurred between the proprietor and the temporary worker upon marking the contract. The use of new techniques and proper methods in buildings and materials in the construction industry still faces many challenges to execution in Southern Iraqi.

Various researchers have worked on topics concerning success in building construction in different fields including construction technique, building problems, Financial and materials selection etc such as research conducted of [] "Success Factors in Construction Projects. The Parliamentary Economics Committee on revealed the existence of 9000 projects that have been suspended since 2005. While confirming that influential party figures and poor management have taken over billions of project funds lagging behind. According to [26], cost control can be achieved by selecting the right man for the right job, the right equipment and tools for the right work and the right quality of materials, in the right quantity, from the right source, at the right price and delivered at the right time. Managers are expected to be well equipped to execute the project, with due consideration to the quality of work, yet within the estimated cost and limit.

Moschouli [12] did a research on an assessment of the organization structure and leadership effects on construction projects' performance in Kenya. [3] studied the factors that influence success in large construction projects. [28] studied emerging trends in economics and management sciences time and cost overruns in power projects in Kenya by closely relating the factors to the various variables. Based on local studies that have been done in Kenya; [27] Factors Affecting the Performance of Construction Projects in Kenya; [26] did a study on causes and effects of cost overrun on public building construction projects in Iraq. But all of them did not focus on key performance indicators of construction projects in Oromia Industry and urban development Bureau, Iraq. From these studies there is no a guideline for the contractors who want to correct their previous mistakes and improve on their current situation. Therefore, this research focused on key performance indicators of construction projects under Oromia Industry and Urban Development Bureau which were used as a benchmarking for the owners, consultants and contractors.

Alaloul [15] studied the causes and effects of cost overrun on public building construction project in Iraq; [24] did studied the analysis of factors contributing to time overruns on building construction projects under Addis Ababa city Administration; [24] studied the role of project planning on project performance in Iraq. From these studies that have been done on cost overruns on construction projects, there is a need for future studies to focus on the following areas: The effects of construction project manager's skills on projects performance. Find out between public and private construction projects, which one has got higher performance level. It is also recommended to develop performance measurement framework and modelling system in order to measure performance of construction organizations and projects. In addition, it is recommended to study and evaluate the most important factors affecting the performance of construction projects.

\section{CONCLUSION}

The contributions of this research review to the sector of construction project management are closely aligned with the research aims represented previously. however, the reader of this thesis deserves to know the intentions, the argument and also the original contribution of the work, and whereas the research is nevertheless to be demonstrated and disseminated within the remainder of this thesis, there's no harm in stating the contributions before. According to previous studies, it could be said that the performance measurement is a process that include factors as Key Performance Indicators (KPIs) such as time, cost, quality, client satisfaction; leadership style and safety in order to enable measurement of current construction projects performance and to achieve significant performance improvements of future projects. It was obtained that there were many fields and topics which are related to performance such as, construction management, information technology, factors affecting performance of managers, measurement of project performance, key performance indicator and benchmarking. The key performance indicators are used to evaluate performance of construction projects. These indicators can then be used for benchmarking purposes, and will be as a key component of any organization to move towards achieving best practice and to overcome performance problem under the Oromia Industry and Urban development Bureau. 


\title{
International Advanced Research Journal in Science, Engineering and Technology
}

\author{
Vol. 6, Issue 5, May 2019
}

\section{REFERENCES}

[1]. Alnaas, K. A. A., Khalil, A. H. H., \& Nassar, G. E. (2014). Guideline for preparing comprehensive extension of time (EOT) claim. HBRC Journal, 10(3), pp. 308-316.

[2]. Alnuaimi, A.S. et al., 2010. Causes, effects, benefits, and remedies of change orders on public construction projects in Oman.

[3]. Long, H., \& Lien, Y. (2018). ScienceDirect Goal orientations, leader-leader exchange, trust, and the outcomes of project performance. International Journal of Project Management, 36(5), 716-729. https://doi.org/10.1016/j.ijproman.2018.03.009.

[4]. Kissi, E., Agyekum, K., Baiden, B. K., Tannor, R. A., Asamoah, G. E., Andam, E. T., ... Baiden, B. K. (2019). Impact of project monitoring and evaluation practices on construction project success criteria in Ghana. Built Environment Project and Asset Management. https://doi.org/10.1108/BEPAM-11-2018-0135.

[5]. Egwunatum, S. I. (2018). MOJ Civil Engineering A Review of Construction Project Performance Estimators. MOJ Civil Eng 2017, 3(4)(September 2017), 14-17. https://doi.org/10.15406/mojce.2017.03.00075

[6]. Rooij, M. M. G. De, Janowicz-panjaitan, M., \& Mannak, R. S. (2019). ScienceDirect A configurational explanation for performance management systems' design in project-based organizations. International Journal of Project Management,37(5),616-630. https://doi.org/10.1016/j.ijproman.2019.03.002.

[7]. Construction industry transformation program (2015), Construction Industry Development Board, Malaysia. retrieved on-line on November, 2015. http://www.cidb.gov.my/cidbv5/index.php/warga-cidb

[8]. Larsson, J. (2018). The importance of hard project management and team motivation for construction project performance. International Journal of Managing Projects in Business, 11(2), 275-288. https://doi.org/10.1108/IJMPB-04-2017-0035.

[9]. De Vaus, D., \& de Vaus, D. (2013). Surveys in social research: Routledge.

[10]. De Vries, N. J., \& Carlson, J. (2014). Examining the drivers and brand performance implications of customer engagement with brands in the social media environment. Journal of Brand Management, 21(6), 495-515.

[11]. Abdullah A. Khawam, Nancy S. Bostain, (2019). (2019). Project manager's role in safety performance of Saudi construction. International Journal of Managing Projects in Business. https://doi.org/10.1108/IJMPB-04-2018-0087

[12]. Moschouli, E., Murwantara, R., \& Vanelslander, T. (2019). Research in Transportation Economics Cost performance of transport infrastructure projects before and after the global financial crisis ( GFC ): Are differences observed in the conditions of project performance ? Research in Transportation Economics, (February), 1-15. https://doi.org/10.1016/j.retrec.2019.02.004.

[13]. Hussein, B.A, Ahmad, S.B, \& Zidane, Y.J. (2015). Problems associated with defining project success. Procedia Computer Science, 64, $940-947$

[14]. Sirisomboonsuk, P., Ching, V., Qing, R., \& Burns, J. R. (2018). ScienceDirect Relationships between project governance and information technology governance and their impact on project performance. International Journal of Project Management, 36(2), 287-300. https://doi.org/10.1016/j.ijproman.2017.10.003.

[15]. Alaloul, W. S., Liew, M. S., Amila, N., \& Abdullah, W. (2016). Identification of coordination factors affecting building projects performance. Alexandria Engineering Journal, 55(3), 2689-2698. https://doi.org/10.1016/j.aej.2016.06.010.

[16]. Jabatan Laut Malaysia. (2015). List of Malaysian containers, oil tankers and fishing ports. retrieved on-line on November, 2015. www.marine.gov.my. www.mot.gov.my.

[17]. Malaysia household debt to GDP. (2013). retrieved on-line on November, 2015. https://www.google.com/search?q=bank+negara+malaysia+household+debt.

[18]. Malaysia oil and gas report. (2016), retrieved on-line on November, 2015. https://community.ump.edu.my/ecommstaff/sites/default/library/subfolders/1278 0/1/BMI_Malaysia_Oil_26_Gas_Report_Q12016.pdf.

[19]. Marzook, M.M, \& El-Rasas, T.I. (2014). Analyzing delay causes in Egyptian construction projects. Journal of Advanced Research, 5(1), 49-55.

[20]. Olugbenga Jide Olaniran, (2015). (2015). The effects of cost-based contractor selection on construction project performance. Journal of Financial Management of Property and Construction, 20(3), 235-251. https://doi.org/10.1108/JFMPC-06-2014-0008.

[21]. Puspadevi, S. (2015). Obstacles to construction growth, The Star Online, Business news. retrieved on-line on November, 2015. http://www.thestar.com.my/Business/Business-News/2015/01/02/Obstacles-toconstruction-growth.

[22]. Sami Kärnä, Juha-Matti Junnonen, (2016). (2016). Benchmarking construction industry , company and project performance by participants , evaluation. Benchmarking: An International Journal, 23(7), 2092-2108. https://doi.org/10.1108/BIJ-05-2015-0050.

[23]. Van Berkel, F.J., Ferguson, J.E., \& Groenewegen, P. (2016). Speedy delivery versus long term objectives: How time pressure affects coordination between temporary projects and permanent organizations. Journal of Long Range Planning.

[24]. Van Offenbeek, M.A., \& Vos, J.F. (2016). An integrative framework for managing project issues across stakeholder groups. International Journal of Project Management, 34(1), 44-57.

[25]. Demirkesen, S., \& Ozorhon, B. (2017). ScienceDirect Impact of integration management on construction project management performance. International Journal of Project Management, 35(8), 1639-1654. https://doi.org/10.1016/j.ijproman.2017.09.008.

[26]. Olugbenga Jide Olaniran, (2015). (2015). The effects of cost-based contractor selection on construction project performance. Journal of Financial Management of Property and Construction, 20(3), 235-251. https://doi.org/10.1108/JFMPC-06-2014-0008.

[27]. Zidane, Y. J., Hussein, B. A., \& Ørn, J. (2016). Categorization of organizational factors and their impact on project performance. Procedia Social and Behavioral Sciences, 226(1877), 162-169. https://doi.org/10.1016/j.sbspro.2016.06.175.

[28]. Kobarg, S., Stumpf-wollersheim, J., \& Welpe, I. M.(2019). More is not always better : Effects of collaboration breadth \& depth on radical \& incremental innovation performance at the project level. Research Policy,48(1),1-10. https://doi.org/10.1016/j.respol.2018.07.014. 